
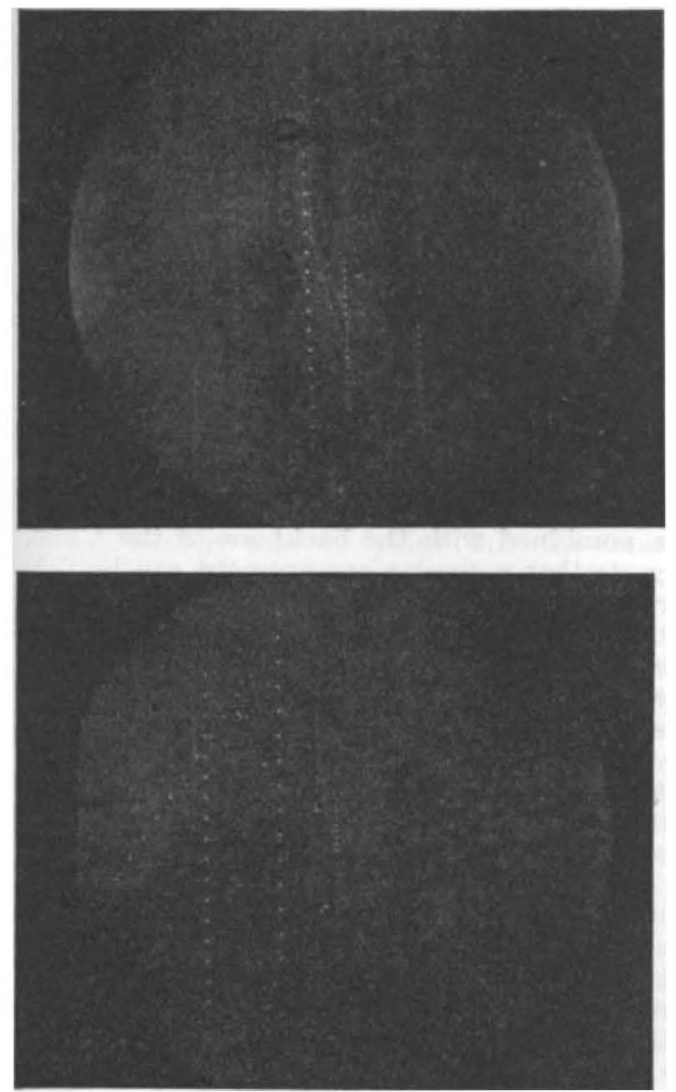

Fig. 2. PHOTOGRAPHS SHOWING PATHS OF DROPS BEFORE AND AFTER THE APPLICATION OF THE ELECTRIC FIELD.

Time interval between the appearance of consecutive images is 0.04 sec. Time of exposure for each image 0.0007 sec. Magnification of camera, $\times 12$.

high orders with optical lines of the spark spectra of carbon, oxygen, etc., the wave-lengths of which Edlén had measured.

Next the wave-length of the X-ray line, $\lambda_{c}$ x.v., is measured using an X-ray spectrometer and a crystal. Since for calcite $\lambda_{c} \mathrm{Al} K \alpha_{12}$ is greater than $2 d$, it cannot be used as the crystal. Mica, gypsum, and quartz crystals have been used. The lattice constant of the crystal used is compared with that of calcite using copper $K \alpha_{1}$ or other homogeneous radiation. The observations of Larsson, Siegbahn and Haglund agree closely, giving $\lambda_{c}$ Al $K \alpha_{12}=8322 \cdot 90$, where, as defined by Siegbahn (and always used by him), 1 x.u. $=d_{18}$ calcite $/ 3029 \cdot 45$.

The expression $e=\left(\lambda_{g} / \lambda_{c}\right)^{3} 4 \cdot 77302 \times 10^{-10}$ is used to calculate $e$; it is calculated using the most probable values of $p, \phi(\beta), F$ and $M$.

\begin{tabular}{|c|c|c|c|}
\hline \multicolumn{4}{|c|}{ X-RAY VALUES OF $e$} \\
\hline Băcklin & $4.8017 \times 10^{-30}$ & Tyrén & $4 \cdot 8020$ \\
\hline Söderman & $4.8027 \times 10^{-10}$ & Bearden (1935) & $4 \cdot 8029$ \\
\hline
\end{tabular}

If $\eta_{23}=1.8301 \times 10^{-4}$, the values of $e$ are : Millikan, 4.799 ; Hopper and Laby, 4.8020 ; X-ray value, $4.8023 \times 10^{-10}$ F.S.U., and the two methods agree.

${ }^{1}$ Hopper, V. D., and Laby, T. H., Proc. Roy. Soc., A, 178, 243 (1941). "Tyrén, F., Z. Phys., 109, 722 (1938).

For reference to other workers mentioned in this paper see reference (1).

\section{GEOLOGY IN CHINA}

\section{ANNIVERSARY OF THE GEOLOGICAL SOCIETY OF CHINA}

$\mathrm{T}$ O say that the activities of Chinese geologists during the past few decades have been remarkable seems almost an understatement: our admiration of their achievements is quickened by the reflection that the Geological Society of China was founded only twenty years ago. Even under the handicap of present conditions, the Society recently celebrated its twentieth anniversary, when Dr. J. S. Lee, as chairman, delivered an inspiring address. We in Great Britain feel gratified when we remember that Dr. Lee is one of the many Chinese geologists trained in a British university (in this case, Birming. ham), and we look forward to a resumption and even an extension of this practice after the War. By this means we make close scientific contacts (which benefit those who give no less than those who take) with a country vast in area, varied in physical features and diversified in rock-types.

In China we see a part of the earth's crust where geological processes have been developed on the grand scale. Although geological history cannot actually repeat itself anywhere, we can usually detect recurrent phases that show mimetic resemblances. Moreover, it would seem that although the principles of geological science are by their very nature applicable to all terrestrial areas, each major unit of the continental surface displays its own peculiar features. For example, the surprising geological discoveries made year by year in Africa remind us that, so early as Pliny's time, men were accustomed to look to Africa for things always new. Since then, North America, India and the U.S.S.R. have produced their crops of geological novelties; and now we can appropriately apply to China the well-worn aphorism. Even the popular imagination is stirred by such events as the unearthing of fossil dinosaur eggs or the skull of Peking man, but these discoveries are matched by no less remarkable, if more esoteric, discoveries in the fields of mineralogy, palæontology, stratigraphy and tectonics.

The two decades that have elapsed since the foundation of the Geological Society of China have seen great political upheavals in the country, the setbacks due to ideological rivalries and a bitter war of penetration arising out of the economic ambitions of a neighbouring power. Such conditions are certainly not favourable for the prosecution of scientific work, and we cannot but marvel at the way in which our Chinese colleagues have succeeded in carrying on both laboratory research and the primary survey of the rocks of their motherland in spite of manifold difficulties, of which transportation is not the least considerable.

Dr. Lee's review of progress in Chinese geology during the past twenty years is a timely reminder of what can be accomplished in adverse circumstances by devotion to science: it is also a stocktaking which serves to indicate those fields in which more knowledge is urgently needed. At the outset, he directed attention to the "extraordinary fact" (to quote his own words) ". . . how few is the number of papers dealing with the economic aspect of geology that appeared in the bulletin of this society. Among the reasons to account for this record, I would point out one: namely, that a non-utilitarian tendency has always constituted a strong trait in the character of Chinese intelligenzia throughout historical times". 
The misuse of scientific discoveries and the perverted developments elsewhere lead him to the reflection that (as he puts it) handicaps such as those due to the absence in a country of any legacy of geological ideas sometimes turn out to be an advantage. The contrast in outlook is emphasized by the action of the covetous neighbour who has invaded China in order to exploit the natural resources, especially of minerals. Comparatively little is known about the potentialities of the huge area of China which, sensu lato, covers more than one tenth of the earth's land surface : their proper assessment will inevitably call for a large army of investigators, and the information thus acquired will materially affect any action taken to implement the Fourth Article of the Atlantic Chartor.

Dr. Lee notes that the Geological Society of China, although a national organization, is in fact international in character, as witnessed by the roll of members, who come from all lands. Many have participated in the work of the Society and are welcomed in a fraternal atmosphere. As he pointedly says, "we have even adopted the leading Western languages, principally English, as the official means of communication, not without some sacrifice of our own convenience". For this, as also for the fact that he gave his address in English, we are very thankful.

Some of Dr. Lee's animadversions are in the nature of warnings to his geological colleagues not to rely too much on the range of fossils and on stratigraphical divisions established in other parts of the world. $\mathrm{H}_{\theta}$ cites as examples the discovery of the tabulate coral Tetrapora, formerly believed to be typically Permian, in beds so ancient as the Lower Carboniferous; of a species of Sphenophyllum hitherto unknown below the Stephanian coal measures of Europe, in the Wuntung Sandstone of Lower Carboniferous age; and of the Upper Devonian fish Bothriolepis in the lower part of the Middle Devonian. He mentions other instances in order to show that the stratigraphical value and zonal positions of fossils in China are not in conformity with records established elsewhere. There are considerable lacunæ, he says, in the fields of mineralogy and petrology, such as the study of the constituonts of the sedimentary deposits and the natural history of the igneous and metamorphic rocks of China. Both merit further attention, and his country offers generous scope for these lines of inquiry.

The survey of complex petrological provinces has necessarily proceeded slowly and map-making has been delayed, a fact which reminds Dr. Lee to mention incidentally the appearance of a gorgeously coloured geological map of Southern China, published by a foreign institution (and we can make a shrewd guess at its source, knowing which nation specialized in such regional activities) at a time when even the larger units of the stratigraphy were scarcely known! But, as he says, the absenee of authoritative geological maps of China invites such "indignities".

After dealing with the subject of mapping, Dr. Lee is led to a discussion of problems of palæogeography, and he takes the opportunity to warn his colleagues against the danger of inferring the onset of important earth-movements from evidence which denotes nonsequence rather than major unconformity. As a prelude to the discussion of geophysical phenomena and tectonics, he describes examples of rock deformations that may astonish Western workers, such as the yielding of tombstones under their own weight and of the bending of pebbles of chert and hard sandstone under a load of ice only $100 \mathrm{~m}$. in thickness.

Dr. Le日's early attempts to classify the structura] features and mountain forms of China are well known to us, for they found publicity in an English geological journal. In his view, these features fall into three dominant groups, the Cathaysian and Neo-Cathaysian trends (the former dating from the Palæozoic and generally running north-eastwards, and the latter probably late Mesozoic and running north-northeastwards), the east-west fold-zones, and the various shear-forms. The dominant shear-forms, five or six in number, are of his epsilon-type and each extends over the whole or part of a segment of the continent and is separated from the other by fold zones, their arcuate convex fronts facing the equator. Dr. Lee sees this structure also in the sweep of the Eurasian arcs, combined with the backbone of the Urals, and suggests that a similar arrangement can be found in North America. From experimental results in the laboratory, he infers that these features are characteristic of the behaviour of a plasto-elastic material when subjected to stresses, and that in the earth's crust they result from "the horizontal component of the centrifugal force arising from the spin of the earth, or more probably from an increase of its rotational speed". Dr. Lee admits that his generalizations are likely to arouse scepticism in some quarters. He makes reference also to a rather better known effect of the earth's rotation when he records that, like the meridionally flowing rivers of Russia, the mighty Yangtze is at the present time undercutting steeply its right-hand bank after it leaves the gorges.

Dr. Lee concludes his address with a summary of the evidence for a polyphase Ice Age in China, in which there were not less than three separate glacial episodes. Incidentally, he correlates one with the "Würm of Europe": now, the Würm episode in the Alps is generally known, but opinions differ widely about the particular phenomena that distinguish its traces elsewhere.

Although only a few of its many interesting points can be mentioned here, we may take this opportunity to hail the address as contributory evidence of the virility of young China. P. G. H. Boswerc.

\section{ELECTRON LENSES*}

$$
\begin{gathered}
\text { By DR. D. GABOR } \\
\text { Research Laboratory of The British Thomson Houston } \\
\text { Co. Ltd., Rugby }
\end{gathered}
$$

A S soon as $H$. Busch had established the analogy A between axially symmetrical electromagnetic fields and optical lenses, a question very naturally suggested itself : "Can we make electron lenses as perfect as the highly corrected lenses of modern optics?"

Compared with light optics the new science started with a great advantage, and with a great disad. vantage. Whereas in optical instruments the ratio of refractive indexes never exceeds $2: 1$, in electronic devices we can realize ratios of $1000: 1$ or more, by using sufficiently high accelerating voltages. Against this stood the great disadvantage that while modern applied optics has a great variety of glasses at its

"Substance of part of a lerture on "Electron Optics" bcfore the Fjectronies Group of the Institute of Physics drlivered on October 81 . 